\title{
Raw material supplier selection in a glove manufacturing: Application of AHP and fuzzy AHP
}

\author{
Ririn Diar Astantia ${ }^{\mathrm{a}}$, Stephanie Eka Mbolla ${ }^{\mathrm{a}}$ and The Jin $\mathbf{A i}^{\mathbf{a}^{*}}$
}

\begin{tabular}{|c|c|}
\hline CHRON I CLE & A B S T RACT \\
\hline $\begin{array}{l}\text { Article history: } \\
\text { Received April 5, } 2020 \\
\text { Received in revised format: } \\
\text { May 9, } 2020 \\
\text { Accepted May } 202020 \\
\text { Available online } \\
\text { May 20, 2020 } \\
\text { Keywords: } \\
\text { Supplier selection problem } \\
\text { Priority } \\
\text { AHP } \\
\text { Fuzzy AHP }\end{array}$ & $\begin{array}{l}\text { This paper considered a case of supplier selection problem in a glove manufacturer located at } \\
\text { Yogyakarta, Indonesia that uses genuine sheep leather as the raw material. The problem is solved } \\
\text { using both Analytical Hierarchy Process (AHP) and Fuzzy AHP, in which three versions of } \\
\text { Fuzzy AHP are applied i.e. Extent Analysis proposed by Chang (1996) [Chang, D. Y. (1996). } \\
\text { Applications of the extent analysis method on fuzzy AHP. European Journal of Operational } \\
\text { Research, 95(3), 649-655.], Extent Analysis proposed by Wang (2008) [Wang, Y. M., Luo, Y., } \\
\text { \& Hua, Z. (2008). On the extent analysis method for fuzzy AHP and its applications. European } \\
\text { Journal of Operational Research,186(2), 735-747.], and the modified Fuzzy LLSM proposed by } \\
\text { Wang (2006) [Wang, Y. M., Elhag, T. M., \& Hua, Z. (2006). A modified fuzzy logarithmic least } \\
\text { squares method for fuzzy analytic hierarchy process. Fuzzy Sets and Systems, 157(23), 3055- } \\
\text { 3071.]. Moreover, the research is conducted by incorporated four expert respondents, who have } \\
\text { more than } 12 \text { years of experience in the problem. It is found that the top four priorities obtained } \\
\text { from AHP are similar with those from Fuzzy AHP with Extent Analysis proposed by Chang } \\
\text { (1996) and Fuzzy AHP with the modified Fuzzy LLSM proposed by Wang (2006). This priority } \\
\text { list of supplier can be used by the manufacturer to select the raw material supplier. }\end{array}$ \\
\hline
\end{tabular}

C) 2020 by the authors; licensee Growing Science, Canada.

\section{Introduction}

Raw material places many important roles in the production process. Without enough quantity of raw material, the production process can be interrupted. In addition, the quality of raw material affects the quality of finished product. The case presented in this paper took place in a glove manufacturer company located at Yogyakarta, Indonesia, which produces gloves from genuine sheep leather as the raw material. From initial observation, it is known that the quality of glove is directly affected by the quality of the sheep leather used. If the sheep leather contains scratch and or stain then the quality of the glove produced would also be reduced. As a company usually receives raw material from its supplier(s) therefore having a good supplier that would enable the company to have the material at the right quantity, in the right time, and in the right quality is needed. According to Yadav and Sharma (2016) it is impossible for a company to reach its competitive advantage, i.e. providing product or service with low cost, without having appropriate supplier. In addition, the appropriate vendor may lead to the better performance of the company (Weber et al., 1991; Choi \& Hartley, 1996). Yu and Wong (2014) also stated that competitiveness of a supply chain is influenced by the performance of its suppliers. Therefore a process to select the best supplier is important for the company (Chen et al., 2006; Gencer \& Gürpinar, 2007; Kang \& Lee, 2010; Agarwal et al., 2011). Research on supplier selection have been conducted in various type of industry, such as automotive industries (Choi \&

* Corresponding author

E-mail address: the.jinai@uajy.ac.id (T. J. Ai)

(C) 2020 by the authors; licensee Growing Science, Canada. doi: $10.5267 /$ j.dsl.2020.5.005 
Hartley, 1996; Sagar \& Singh, 2012; Yadav \& Sharma, 2015), electronic firm (Gencer \& Gürpinar, 2007), semiconductor industries (Chan \& Chan, 2004), fast changing fashion market (Chan \& Chan, 2010), furniture sectors (Liu \& Hai, 2005), electrical-electronic sector (Hou \& Su, 2006), pharmaceutical manufacturing firm (Asamoah et al., 2012), and railway industry (Bruno et al., 2012). Qiang and $\mathrm{Li}$ (2015) conducted research on information technology provider selection. Unlike previous mentioned researches, the research in this paper was conducted in a glove manufacturer located in Yogyakarta, Indonesia. In this glove manufacturer, their fulfillment order strategy is make-to-order where most of their customers usually specify quality of leather they want to use. This company has multiple suppliers to supply the leather. The quality of leather is leveled from level 1 until level 11 (I, II, III, IV, V, VI, VII, VIII, R1, R2, R3) where level 1 represents the best quality of leather. The unique characteristics of the suppliers in this company are that each supplier cannot guarantee that they are supplying the same quality of leather from one period to other period. It is because the quality of the leather depends on the quality of their livestock. Therefore, the existing procedure of supplier selection in this company requires a longer time in order for the company to check the whole suppliers regarding availability and quality of leather that they are able to provide. For example if the company received an order from a particular customer where the customer prefer to use level 2 leather as raw material, then if the company do not have stock of level 2 leather, they will check which suppliers that are able to provide them level 2 leather. The procedure is as follows: first the company selects arbitrarily one of their suppliers. Then, they ask if the selected supplier is able to provide level 2 leather with right quantity and right time. If it is not, then the company starts searching for other supplier. They keep doing this activity until the company get or find the supplier that are able to provide the leather with the right quality, in the right quantity, and in the right time as they are expected. Therefore, this current company's procedure to find supplier is not efficient yet. Beside the efficiency issues, other important things is that if the customer prefer to order gloves using level 2 leather, product price has set according to price of level 2 leather. However if the company is not able to provide level 2 leather but level 1 leather, therefore, it generates higher raw material cost. In addition, it is not possible to increase product price that has been offered to the customer. An alternative for overcoming this situation is by providing the company with the priority list of their supplier. Therefore, they will refer to that priority whenever they are looking for the right supplier. It is expected that the effort for searching appropriate vendor can be minimized and the company profit will not be reduced due to unavailability of appropriate raw material. This fact emphasizes the importance of this problem of vendor selection in a glove manufacturer located in Yogyakarta, Indonesia.

This paper is organized as follows: Section 2 presents a literature review in supplier selection problem including its methods and its application. Section 3 explains the problem description, Section 4 report the case result using AHP, Section 5 report the case result using Fuzzy AHP, Section 6 discuss the result obtained, and followed by Section 7 that present the conclusion.

\section{Literature Review}

In this intense business competition, supplier plays important role that enable the company to reach its competitive advantages (Liu \& Hai, 2005; Chen et al., 2006; Yadav \& Sharma, 2016). Therefore, the process to select the best supplier is crucial for every organization. Supplier selection itself is one the activity in the purchasing process. According to de Boer et al. (2001) purchasing process has to be done systematically. Research on supplier selection problem received much attention from the researchers. Numerous works in this area have been discussed in the literature. Weber et al. (1991) reviewed previous researches on vendor selection in Just-in-Time environment. In addition, Weber et al. (1991) stated that the supplier selection problem considers multi criteria. Timmerman (1987), Ghodsypour and O'Brien (1998), Agarwal et al. (2011), Yadav and Sharma (2016), Yildiz and Yayla (2015) have also stated that vendor selection problem is a multi criteria decision making problem. It can be seen that in most of cases, supplier selection problem use more than one criteria as a basis for selection the best supplier (Choi \& Hartley, 1996; Fawcett et al., 1997, Li et al., 1997; Motwani et al.,1998; Olhager \& Selldin, 2004; Mendoza et al., 2008). According to Liu and Hai (2005), different companies might 
apply different criteria concerning supplier selection. Based on those previous researches, it can be concluded that the step in supplier selection process started with the selection of criteria that have to be used to select the best supplier. According to de Boer et al. (2001) this step is called as pre-qualification stage in the supplier process. Several methods have been reported to deal with the problem of determining the suitable criteria for vendor selection, such as: cluster analysis (Holt, 1998; Che, 2010) and case base reasoning (Choy et al., 2003). After selecting criteria, then the next step is final choice. Numerous researches have been conducted dealing with the final choice step in the supplier selection process. Five methods have been reported previous researches dealing with decision models for the final choice-phase (de Boer, 2001). They are: Linear Weighting Model, Total Cost Ownership (Degraeve et al., 2000), Mathematical Programming (Talluri \& Narasimhan, 2003; Choy et al., 2003; Talluri, 2002; Ghodsypour \& O’Brien, 1998; Zhu, 2004), Statistical Models, Artificial Intelligence (AI) - based models (Choy et al., 2003). de Boer (2001) reported that Analytical Hierarchy Process (AHP) and Analytic Network Process (ANP) are included in the linear weighting model. Recently, Mohaghar et al. (2013) proposed an integration of fuzzy VIKOR and AR-DEA for the final choice. Some methods can be considered as optimization approach where in order to use those methods, the quantitative criteria are needed. However, in the supplier selection problem sometimes the company has to consider both quantitative criteria such as product price and qualitative data such as vendor reputation. In that case, AHP method developed by Saaty (1980) is a powerful tool for supplier selection problem. Previous researches have been found related to the use of AHP for supplier selection problem such as Chan (2003), Liu and Hai (2005), Asamoah et al. (2012), Bruno et al. (2012), Perçin (2006), Ramanathan (2007), Sevkli et al. (2007), Kokangul and Susuz (2009), Chamodrakas et al. (2010), Rajesh and Malliga (2013), Chan and Kumar (2007), Killincci and Onal (2011), Khorasani and Bafruei (2011), Rezaei et al. (2014). The criteria and sub criteria discussed in the previous research can be seen in Table 1.

Table 1

Criteria and sub criteria used in the previous researches on supplier selection

\begin{tabular}{|c|c|c|}
\hline & Criteria & Sub criteria \\
\hline 1 & $\begin{array}{l}\text { Qualitative } \\
\qquad \begin{array}{l}\text { Service } \\
\text { Wilson, 1994; Bhutta and Huq, 2002; Mirabi et al., } \\
\text { 2010; Mendoza, 2007; Li et al., } 2013\end{array}\end{array}$ & $\begin{array}{l}\text { Flexibility } \\
\text { Wilson, 1994; Çebi and Bayraktar, 2003; Nayak et al., 2011; Mirabi et al., 2010, } \\
\text { Thakkar et al., } 2012 \\
\text { Capability of managing risk related to: } \\
\text { Low quality product } \\
\text { Azizi and Modarres, } 2010 \\
\text { Increase in production cost } \\
\text { Azizi and Modarres, } 2010 \\
\text { Delay delivery of material } \\
\text { Azizi and Modarres, } 2010 \\
\text { Delivery } \\
\text { Wilson, 1994; Kumar Kar and Pani, 2014; Çebi and Bayraktar, 2003; Paksoy et al., } \\
\text { 2013; Vonderembse and Tracey, 1999; Mafakheri et al., 2011; Choi and Chang, } \\
\text { 2006; Nazari-Shirkouhi, et al., 2013; Kannan et al., 2013 } \\
\text { Technical Support } \\
\text { Wilson, } 1994\end{array}$ \\
\hline 2 & $\begin{array}{l}\text { Quality } \\
\text { Wilson, 1994; Kumar Kar and Pani, 2014; Jayaraman } \\
\text { et al., 1999; Bhutta and Huq, 2002; Gnanasekaran et } \\
\text { al., 2006; Paksoy et al., 2013; Vonderembse and } \\
\text { Tracey, 1999; Asamoah et al., 2012; Gonzales et al., } \\
\text { 2004; Weber and Elram, 1993; Hsu et al., 2014; Mirabi } \\
\text { et al., 2010; Thakkar et al., 2012; Mendoza, 2007; } \\
\text { Mafakheri et al., 2011; Choi and Chang, 2006; Nazari- } \\
\text { Shirkouhi et al., 2013; Kannan et al., 2013; Li et al., } \\
2013\end{array}$ & $\begin{array}{l}\text { Financial power } \\
\text { Kumar Kar and Pani, 2014, Çebi and Bayraktar, } 2003 \\
\text { Reputation and vendor position in the market } \\
\text { Wilson, 1994; Çebi and Bayraktar, 2003; Asamoah et al., 2012; Li et al., } 2013 \\
\text { Management and compatibility } \\
\text { Çebi and Bayraktar, 2003; Vonderembse and Tracey, 1999; Asamoah et al., } 2012 \\
\text { Relationship with the vendor (Çebi and Bayraktar, 2003) such as: } \\
\text { Communication } \\
\text { Çebi and Bayraktar, 2003; Asamoah et al., } 2012 \\
\underline{\text { Past experience }} \\
\text { Çebi and Bayraktar, 2003; Li et al., } 2013 \\
\text { Sales representative competence } \\
\text { Kumar Kar and Pani, 2014, Çebi and Bayraktar, 2003; Nayak et al., 2011; Thakkar } \\
\text { et al., 2012; Li et al., 2013 } \\
\frac{\text { Dedication }}{\text { Nayak et al., } 2011} \\
\underline{\text { Trust }} \\
\text { Nayak et al., } 2011\end{array}$ \\
\hline
\end{tabular}




\section{Table 1}

Criteria and sub criteria used in the previous researches on supplier selection (Continued)

\begin{tabular}{|c|c|c|}
\hline & Criteria & Sub criteria \\
\hline 3 & $\begin{array}{l}\text { Technological capability } \\
\text { Kumar Kar and Pani, } 2014\end{array}$ & $\begin{array}{l}\text { Technology } \\
\text { Kumar Kar and Pani, 2014; Bhutta and Huq, 2002; Çebi and Bayraktar, 2003; Kannan } \\
\text { et al., } 2013 \\
\text { Production facility } \\
\text { Asamoah et al., } 2012\end{array}$ \\
\hline 4 & $\begin{array}{l}\text { Delivery } \\
\text { Wilson, 1994; Kumar Kar and Pani, 2014; } \\
\text { Mendoza, 2007; Mafakheri et al., 2011 } \\
\end{array}$ & $\begin{array}{l}\text { Delivery time } \\
\text { Gnanasekaran et al., 2006; Asamoah et al., 2012; Gonzales et al., 2004; Weber and } \\
\text { Elram, 1993; Mirabi et al., } 2010\end{array}$ \\
\hline 5 & $\begin{array}{l}\text { Price } \\
\text { Kumar Kar and Pani, 2014; Jayaraman et al., 1999; K } \\
\text { Asamoah et al., 2012; Weber and Elram, 1993; Thak } \\
\text { Li et al., 2013; Nazari-Shirkouhi et al., 2013 }\end{array}$ & $\begin{array}{l}\text { Innan et al., 2013; } \\
\text { ar et al., 2012; }\end{array}$ \\
\hline 6 & Economy & 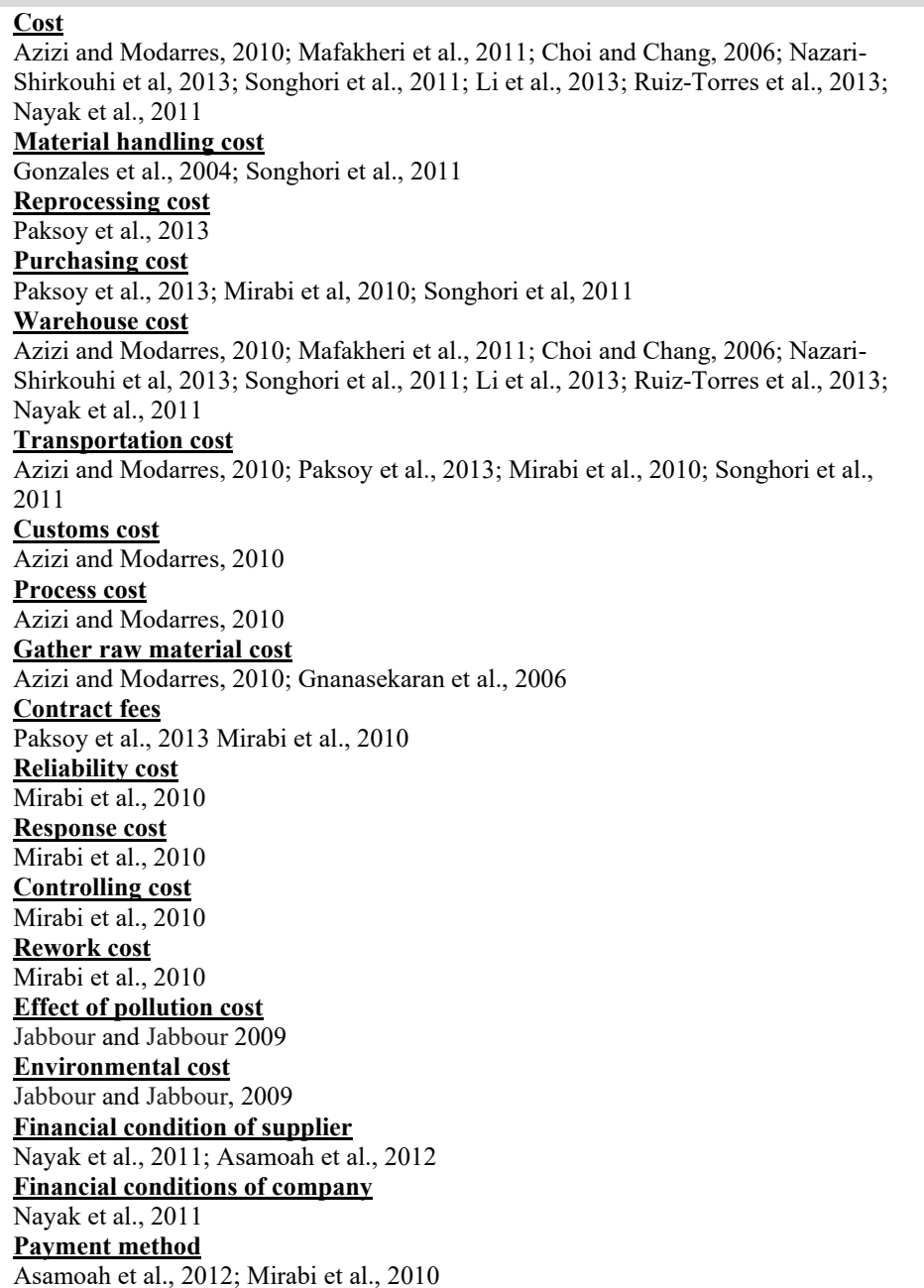 \\
\hline 7 & $\begin{array}{l}\text { Capacity } \\
\text { Jayaraman et al., 1999; Gnanasekaran et al., } 2006 \\
\text { Paksoy et al., 2013; Asamoah et al., 2012; Nazari- } \\
\text { Shirkouhi et al., 2013; Ruiz-Torres et al., 2013; } \\
\text { Songhori et al., 2011; Li et al., 2013; Kannan et al., } \\
2013\end{array}$ & $\begin{array}{l}\text { Production capability } \\
\text { Kumar Kar and Pani, 2014; Bhutta and Huq, 2002; Mirabi et al., } 2010 \\
\text { Storage capacity } \\
\text { Jayaraman et al., 1999; Songhori, } 2011 \\
\text { Availability of product } \\
\text { Çebi and Bayraktar, 2003; Gnanasekaran et al., 2006; Vonderembse and Tracey, 1999; } \\
\text { Gonzales et al., 2004; Mirabi et al., 2010; Thakkar et al., 2012; Ruiz-Torres et al., } \\
\text { 2013; Songhori et al., 2011; Li et al., 2013; Kannan et al., 2013 } \\
\text { Supplier lead time } \\
\text { Jayaraman et al., 1999; Çebi and Bayraktar, 2003; Thakkar et al., 2012; Mendoza, } \\
\text { 2007; Songhori et al., 2011; Li et al., 2013; Kannan et al., } 2013 \\
\text { Probability of defect product } \\
\text { Mirabi et al., 2010; Mendoza 2007; Li et al., } 2013\end{array}$ \\
\hline
\end{tabular}

Kahraman et al. (2003) stated that "though the purpose of AHP is to capture expert's knowledge, the conventional AHP still cannot reflect the human thinking style". In addition, the decision maker is also facing the fuzziness dealing with certain problem (Kabir \& Hasin, 2011). Kabir and Hasin (2011) also 
stated that for assessing qualitative aspect that is not supported by quantitative data, the human being tends to be subjective. Therefore, if the human being is asked to judge the qualitative aspect it might be imprecise. The research on fuzzy AHP especially in the area of supplier selection problem have been found such as: Kahraman et al. (2003), Shaw et al. (2012), Kilinci and Onal (2011), Chamodrakas et al. (2010), Benyoucef and Canbolat (2007), Chan et al. (2008), Haq and Kannan (2006), Kuo et al. (2010), and Tyagi et al. (2015). Some other research also tried to conduct comparative analysis between fuzzy AHP and AHP in the case study, i.e. Kabir and Hasin (2011), Özdağoğlu and Özdağoğlu (2007). If one compared the total priority obtained from AHP and fuzzy AHP in both researches, it is found that the top priorities, i.e. the first three priorities, from both methods are actually the same. Therefore, if someone is facing a decision making problem that require selecting only one alternative, the conclusion from both AHP and fuzzy AHP are indifferent. In other words, using fuzzy AHP is meaningless. However, if the decision making problem requires ranking of alternatives as the result, the output from AHP and fuzzy AHP may different in the middle to low priorities. In this research, another comparative analysis between AHP and fuzzy AHP in the case of supplier selection problem is conducted by using experts in the field who has more than 12 years experiences of selecting supplier in the company. It is expected that this research is able to study the effect of expertise on the differences between AHP and fuzzy AHP results.

\section{Problem Description}

The company observed in this study is a glove manufacturer located in Yogyakarta Indonesia. The raw material is leather that is supplied by 10 suppliers. As it is mentioned in previous section, the suppliers are able to supply with a wide range of qualities from level 1 to level 11 namely level I, II, III, IV, V, VI, VII, VIII, R1, R2, R3. The division is based on the quality of the percentage of the number of defects in one sheet of leather. The supplier is not exclusively supply the raw material to this company. This situation happens because they also supply the raw material to other companies. Therefore, if the decision to select the right supplier take such a long time, therefore there is possibility that the other companies that are able to make a decision faster is able to make a deal with the supplier faster. It increases the possibility for this company to have the shortage of raw material with desired specifications. Business Process of Procurement in this company is shown in Fig. 1. From the Business Process of Procurement presented in Figure 1, it can be seen that Supplier Selection is one of the activity in the business process. Recently, the process of determining the supplier this company is done intuitively and has no standard procedure yet. After knowing the supplier data such as the telephone number the purchasing staff starts calling the suppliers arbitralily. It is because the company do not have rank of suppliers. When this staff calls the supplier he asks to the supplier regarding the following information: 1) availability of raw material at the desired quantity; 2) Price.; 3) Payment term. If the supplier is able to provide the material with right quantity and right quality then, the purchasing staff inform this to the Purchasing Manager and the Purchasing Manager start negotiating the price and payment term. If everything has been agreed then the Purchasing Manager ask the Purchasing Staff to issue the Purchase Order. If it is not then the Purchasing Staff will try to call other supplier. He keeps on doing this activity until all the raw material needed are able to be supplied by the selected supplier. However, the situation that has been found in this company is that because the company do not have rank of suppleirs therefore it takes time for the Purchasing Staff to find the supplier(s) that are able to provide the raw material with the right quality, quantity and time. Looking at these conditions, it is very important for this company to determine the priority of supplier. This priority is then can be used by the company to decide which supplier that has to be called first if they need a raw material to be supplied. 


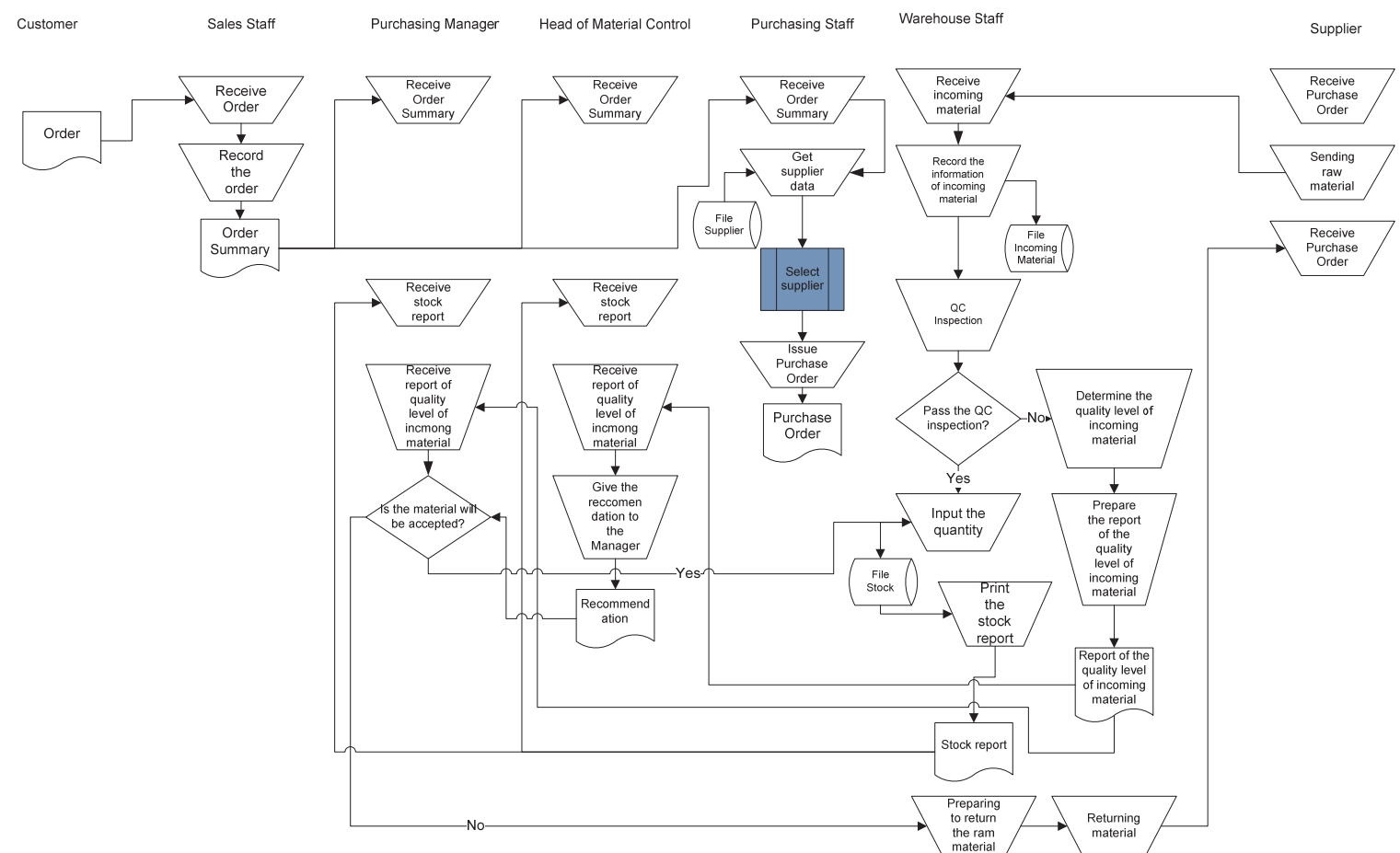

Fig. 1. Business Process of Procurement

\section{AHP Methodology}

In this research an observation to see the current practice of supplier selection in a glove manufacturer located in Yogyakarta Indonesia was conducted. An observation was done by observing the procurement activity in this company. The observation was conducted by:1) interviewing Purchasing Staff; 2) interviewing Head of Material Control; 3) interviewing Purchasing Manager; 3) interviewing Purchase Planner; 4) studying the procurement document which is ASA-PSM-09 Rev:00.; 5) studying the documents, forms, and reports related to the procurement activity. Purchasing Manager, Warehouse Staff, Purchasing Staff, and Head of Material Control are considered as the experts in this study. The profile for the experts in this study is shown in Table 2.

Table 2

Profile of the experts

\begin{tabular}{|c|c|c|}
\hline Position & Job Description & Experience (years) \\
\hline Purchasing Manager & $\begin{array}{l}\text { 1. Approving proposal of the procurement plan } \\
\text { 2. Approving selected supplier } \\
\text { 3. Determining raw material price } \\
\text { 4. Determining quantity of the purchased raw material } \\
\text { 5. Determining whether the quality of the goods received meet the } \\
\text { specification }\end{array}$ & 16 \\
\hline Head of Material Control & $\begin{array}{l}\text { 1. Processing incoming material including inspecting } \\
\text { raw material } \\
\text { 2. Recording the quantity of incoming material }\end{array}$ & 13 \\
\hline $\begin{array}{c}\text { Supervisor/ } \\
\text { Purchasing staff }\end{array}$ & $\begin{array}{l}\text { 1. Creating purchase orders of raw materials } \\
\text { 2. Making a payment plan of purchase orders } \\
\text { 3. Contacting suppliers of raw materials }\end{array}$ & 12 \\
\hline Purchasing planner & $\begin{array}{l}\text { 1. Calculating the quantity of the raw material that need to be bought } \\
\text { according to monthly production planning } \\
\text { 2. Making the analysis related to the shortage of the raw material } \\
\text { 3. Help the supplier selection process }\end{array}$ & 14 \\
\hline
\end{tabular}

The result from this step Business Process of Procurement in this company as it is presented in Figure 1 in the previous section. Once the business process of procurement was constructed then it can be 
identified that the problem is related to the supplier selection. Therefore, the next step was conducted related to the supplier selection in the company such as the number of suppliers they have, the performance of supplier especially the probability that the supplier was not able to meet the specified quality or it called as quality reduction. The characteristics of each supplier in the company can be seen in Table 3.

\section{Table 3}

Characteristics of the supplier

\begin{tabular}{lll}
\hline Supplier & $\begin{array}{l}\text { Scale of } \\
\text { Supplier }\end{array}$ & $\begin{array}{l}\text { Quality } \\
\text { Reduction (\%) }\end{array}$ \\
\hline B & Large & 25 \\
D & Large & 12 \\
E & Large & N/A \\
F & Large & 11 \\
H & Large & 40 \\
I & Small & 15 \\
J & Small & 13 \\
K & Small & 20 \\
L & Small & N/A \\
M & Small & N/A \\
\hline
\end{tabular}

From Fig. 1 it is seen that Supplier Selection is one of activity in the Procurement activity in this company. The next step was structuring the problem of Supplier Selection. This step was conducted by conducting discussion and interview with Purchasing Staff, Head of Material Control, and Purchasing Manager. In addition, studying the Procurement document in the company which is ASA_PSM-09 Rev: 00 was also conducted. During this step it was found that several criteria that are considered by the company in conducting the supplier selection as it is explained in Table 4.

\section{Table 4}

Factors considered by the company to select their suppliers

\begin{tabular}{|c|c|}
\hline Criteria & Description \\
\hline $\begin{array}{l}\text { Percentage of Quality } \\
\text { Reduction }\end{array}$ & $\begin{array}{l}\text { In this company, they classify the quality of sheep leather provided by the supplier in to several category } \\
\text { namely: level I - IV, V, VI, VII and R1, R2, R3 } \\
\text { When their customer place an order to this company usually they mention about the preference of the } \\
\text { quality level of sheep leather they want. For example: a customer might place an order of } 1000 \text { pairs of } \\
\text { gloves where the quality level of sheep leather they want is level I. } \\
\text { The characteristic of their supplier is that their supplier might supply the sheep leather where its quality } \\
\text { might vary from time to time. As it is mentioned in Table 1, the probability that the supplier was not able } \\
\text { to meet the specified quality or it called as quality reduction. The company prefers to have a supplier who } \\
\text { has smaller quality reduction. }\end{array}$ \\
\hline Price & $\begin{array}{l}\text { According to information received from the company it is said that the price of raw material affect up to } \\
60 \% \text { of the financial condition of the company. Therefore, selecting a supplier that provides the competitive } \\
\text { price is expected. }\end{array}$ \\
\hline Supplier capacity & $\begin{array}{l}\text { This factor related to the amount of sheep leather can be provided by the supplier when there is demand. } \\
\text { When the company needs to buy sheep leather with certain quality level, actually the company prefers } \\
\text { when they contact a supplier then that supplier will have enough raw material. Therefore there is no need } \\
\text { for the company to find another supplier. }\end{array}$ \\
\hline Transportation Cost & $\begin{array}{l}\text { The transportation cost is the cost that has to be paid by the company to transport the raw material from } \\
\text { the supplier warehouse to manufacturer warehouse. Currently, the suppliers of this company are located in } \\
\text { East Java, Central Java and East Java. }\end{array}$ \\
\hline Payment Term & $\begin{array}{l}\text { Payment term related to the method of payment and duration of payment. Some suppliers allow the } \\
\text { company to make a payment } 10-14 \text { days after the material has been received. But some other suppliers } \\
\text { may not. For certain supplier this might be negotiable but for other supplier might not. }\end{array}$ \\
\hline Delivery Time & In term of on time delivery \\
\hline Supplier policy & In term of willingness of the supplier to receive the returned raw material that does not meet the quality \\
\hline Supplier commitment & $\begin{array}{l}\text { In term of the commitment from the supplier to provide the amount of raw material as it is stated in the } \\
\text { contract document }\end{array}$ \\
\hline
\end{tabular}

Among those criteria that have been considered by this company, it can be seen from the Table 1 that several criteria that have been discussed in the previous research also become criteria that re used by this company. For example, criteria Price have been used in the previous research, such as Kumar Kar 
and Pani (2014), Jayaraman et al. (1999), Kannan et al. (2013), Asamoah et al. (2012), Weber and Elram (1993), Thakkar et al. (2012), Li et al. (2013), Nazari-Shirkouhi et al. (2013). Transportation cost have been studied by Azizi and Modarres (2010), Paksoy et al. (2013), Mirabi et al. (2010), Songhori et al. (2011). Payment method have been studied by Asamoah et al. (2012), Mirabi et al. (2010). In this research, those 3 criteria are grouped in to 1 criteria which is Economy. Other criteria such as supplier capacity have been studied by previous researches such as Çebi and Bayraktar (2003), Gnanasekaran et al. (2006), Vonderembse and Tracey (1999), Gonzales et al. (2004), Mirabi et al. (2010), Thakkar et al. (2012), Ruiz-Torres et al. (2013), Songhori et al. (2011), Li et al. (2013), Kannan et al. (2013). Other criteria which is on time delivery have been studied also by previous researchers such as Gnanasekaran et al. (2006); Asamoah et al. (2012); Gonzales et al. (2004); Weber and Elram (1993); Mirabi et al. (2010). However the criterion which is percentage of quality reduction has not studied yet in the literature. Even though previous researchers have studied yet the similar criteria related to quality such Mirabi et al. (2010), Mendoza (2007), Li et al. (2013) that mention about the probability of defect product. In this research, the criteria which is supplier capacity, on time delivery and percentage of quality reduction are grouped in to 1 criterion which is Capability. Other criteria that have been found during the interview with the company which are supplier policy and supplier commitment are grouped in to one criterion which is Service. Once all criteria have been identified then the structure of supplier company was identified as it is shown in Fig. 2.

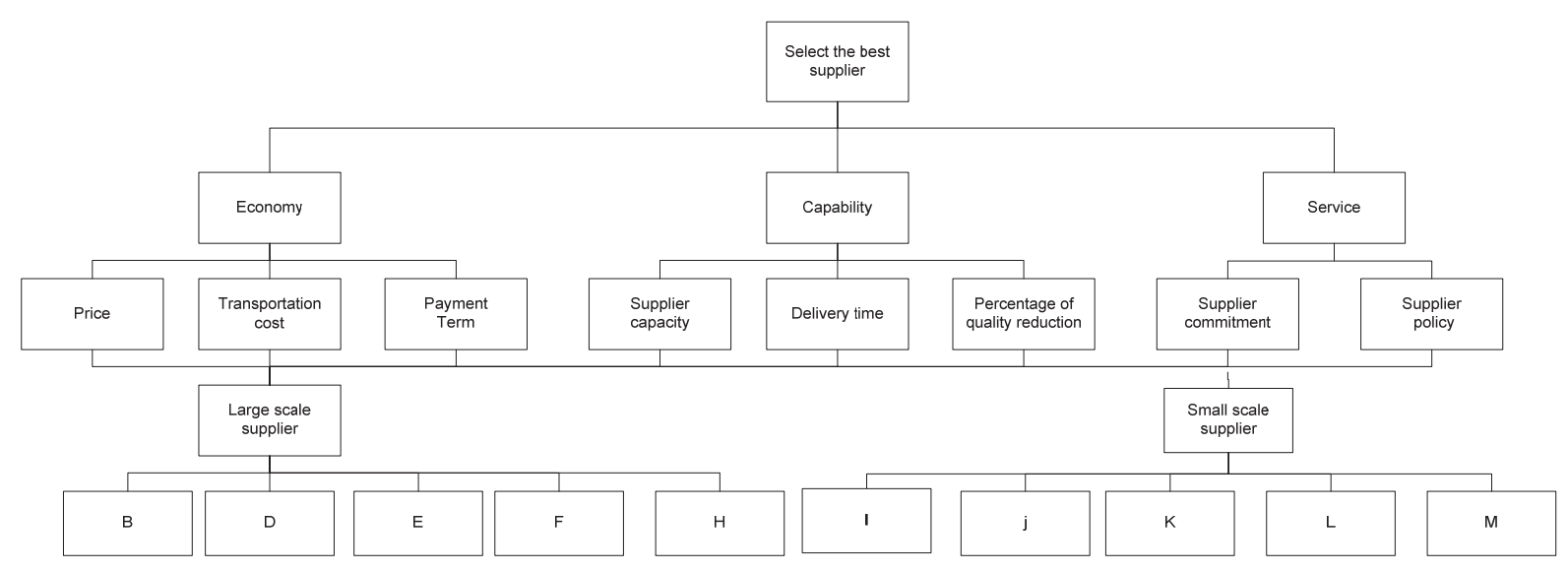

Fig. 2. AHP model for supplier selection

The next step after constructing the AHP model for supplier selection is doing pairwise comparison among criteria. Then the pairwise comparison of all sub criteria with respect to criteria is performed. Basically in this pairwise comparison, a pairwise comparison belonging to a certain level with respect to a higher level is performed. In this step, experts who are Purchasing Manager, Production Planner, Purchasing Staff and Head of Material Control were asked to express their preferences using Saaty's 1-9 scales (Saaty, 1994). Because there are 4 experts, therefore, we had 4 preferences as it is shown in Table 5.

Table 5

Pairwise-comparison among criteria

\begin{tabular}{lccclccc}
\hline Expert 1 & & & & Expert 3 & & \\
\hline Criteria & Economy & Capability & Service & Criteria & Economy & Capability & Service \\
\hline Economy & 1 & 1 & 4 & Economy & 1 & $1 / 3$ & 4 \\
Capability & 1 & 1 & 5 & Capability & 3 & 1 & 6 \\
Service & $1 / 4$ & $1 / 5$ & 1 & Service & $1 / 4$ & $1 / 6$ & 1 \\
\hline Expert 2 & & & & Expert 4 & & & Capability \\
\hline Criteria & Economy & Capability & Service & Criteria & Economy & Service \\
\hline Economy & 1 & 1 & 5 & Economy & 1 & $1 / 4$ & 1 \\
Capability & 1 & 1 & 5 & Capability & 4 & $1 / 6$ & 6 \\
Service & $1 / 5$ & $1 / 5$ & 1 & Service & $1 / 2$ & 1 \\
\hline
\end{tabular}


While in the pairwise comparison matrix only needed one value, therefore, pairwise comparison of each expert are combined into one value. One of the method that can be used is using geometric mean as it is shown in Eq. (1) (Saaty, 1994).

$$
\mu_{i j}=\sqrt[n]{\alpha_{i j 1} \alpha_{i j 2} \cdots \alpha_{i j n}}
$$

where :

$\mu_{i j}=$ Geometric Mean row- $i$ column- $j$

$n$ = number of expert

The pairwise comparison matrix among criteria can be seen in Table 6 .

\section{Table 6}

Pairwise comparison among criteria

\begin{tabular}{llll}
\hline Criteria & Economy & Capability & Service \\
\hline Economy & 1.0000 & 0.5373 & 3.5566 \\
Capability & 1.8612 & 1.0000 & 5.4772 \\
Service & 0.2812 & 0.1826 & 1.0000 \\
\hline
\end{tabular}

The next step after comparative judgment is synthesizing. This step consists of several activities which are:

a. Normalization

Normalize the data by dividing each value in the matrix of pairwise comparison with the total value of the column. Normalization of each column in the matrix of pairwise comparison is calculated by the following formula (Mendoza, 2007):

$$
r_{i j}=\frac{\alpha_{i j}}{\sum_{i=1}^{n} \alpha_{i j}}
$$

where

$r_{i j}=$ the value of the division of the $i$-th row $j$-th column with a total value of $j$-th column

$\alpha_{i j}=$ Value pairs comparison to the $i$-th row $j$-th column

$\sum_{i=1}^{n} \alpha_{i j}=$ Total value of all pairwise comparisons of column $j$

\section{Table 7}

Normalized pairwise comparison matrix

\begin{tabular}{lccc}
\hline Criteria & Economy & Capability & Service \\
\hline Economy & 0.3182 & 0.3124 & 0.3545 \\
Capability & 0.5923 & 0.5814 & 0.5459 \\
Service & 0.0895 & 0.1062 & 0.0996 \\
\hline
\end{tabular}

b. Calculating local priority

Compute the average of the elements in each row of the normalized pairwise comparison matrix. These averages provide an estimate of the relative priorities of the elements being compared. The result is shown in Table 8.

\section{Table 8}

Priority of criteria with respect to goal

\begin{tabular}{lcccc}
\hline Criteria & Economy & Capability & Service & Local Priority \\
\hline Economy & 0.3182 & 0.3124 & 0.3545 & 0.3185 \\
Capability & 0.5923 & 0.5814 & 0.5459 & 0.5813 \\
Service & 0.0895 & 0.1062 & 0.0996 & 0.1002 \\
\hline
\end{tabular}


c. Consistency checking

The calculation of local priority is done by calculating eigenvector and eigenvalue. Eigenvector is the ratio of the weight of each factor while eigenvalue represents the value of the division between matrix multiplication and eigenvector with the eigenvector value. Mathematical expression of the eigenvector $(w)$ and eigenvalue $(\lambda)$ can be formulated as follows (Saaty, 1994):

$$
\begin{aligned}
& A \cdot w=\lambda \cdot w \\
& {\left[\begin{array}{llll}
\frac{w_{1}}{w_{1}} & \frac{w_{1}}{w_{2}} & \cdots & \frac{w_{1}}{w_{n}} \\
\vdots & \vdots & \ddots & \vdots \\
\frac{w_{n}}{w_{1}} & \frac{w_{n}}{w_{2}} & \cdots & \frac{w_{n}}{w_{n}}
\end{array}\right]\left[\begin{array}{c}
w_{1} \\
\vdots \\
w_{n}
\end{array}\right]=\lambda\left[\begin{array}{c}
w_{1} \\
\vdots \\
w_{n}
\end{array}\right]}
\end{aligned}
$$

Based on the results of normalization value eigenvector to economic criteria, capabilities and services in a way that is $0.3185,0.5813$, and 0.1002 . Eigenvector value will be used to determine the eigenvalue. Eigenvalue obtained from the calculation according to equation (3) and (4). Here is the calculation of eigenvalues on the following criteria:

$$
A \cdot w=\lambda \cdot w \quad\left[\begin{array}{lll}
1.0000 & 0.5373 & 3.5566 \\
1.8612 & 1.0000 & 5.4772 \\
0.2812 & 0.1826 & 1.0000
\end{array}\right]\left[\begin{array}{l}
0.3185 \\
0.5813 \\
0.1002
\end{array}\right]=\lambda\left[\begin{array}{l}
0.3185 \\
0.5813 \\
0.1002
\end{array}\right] \quad\left[\begin{array}{l}
0.9872 \\
1.7229 \\
0.2959
\end{array}\right]=\lambda\left[\begin{array}{l}
0.3185 \\
0.5813 \\
0.1002
\end{array}\right]
$$

Therefore, there are three possible values of $\lambda$, which are 3.0997, 2.9636, and 2.9530, and the biggest one, the $\lambda_{\max }$ is equal to 3.0997. After $\lambda_{\max }$ is known then the consistency checking was performed. This checking is performed to measure the quality of the judgment during the series of pairwise comparison performed by experts. The degree of inconsistency is acceptable if the value of consistency ratio (CR) is $\leq 0.10$. If CR is $\geq 0.10$ then the judgment from the experts need to be evaluated (Saaty, 1994). CR value can be calculated by dividing the value of Consistency Index (CI) to the value of Random Consistency Index (RI). Value Consistency Index (CI) is derived from the equation:

$$
C I=\frac{\lambda_{\max }-n}{n-1}
$$

where:

$$
\begin{aligned}
& C I=\text { Consistency Index } \\
& \lambda_{\max }=\text { eigenvalue maximum } \\
& n \quad=\text { matrix order }
\end{aligned}
$$

The average value of Random Index (RI) can be seen in Table 9. It is noted that if the matrix order is equal to 2 , then it is always consistent.

\section{Tabel 9}

Random Consistency Index (RI) (Saaty, 1994)

\begin{tabular}{lcccccccccc}
\hline Matrix Order $(n)$ & 1 & 2 & 3 & 4 & 5 & 6 & 7 & 8 & 9 & 10 \\
\hline $\begin{array}{l}\text { Random } \\
\text { Index }(\mathrm{RI})\end{array}$ & Consistency & & & & & & & & & \\
\end{tabular}

For this case, since $\lambda_{\max }$ is equal to 3.0997 with $n$ is equal to 3 , therefore, CI is equal to 0.0498 . From Table 9, it is known that RI is equal to 0.52 the respective value of $n$. Therefore, CR is equal to 0.0958 . Hence, this comparison is consistent. 
Using similar procedure, the local priority and consistency checking for the sub criteria, alternative and sub alternatives can be obtained. The results are presented in Table 10 and 11. It is noted that Table 11 is only presenting the result of comparison with $n$ greater than 2 .

\section{Table 10}

Local Priority of each Comparison

\begin{tabular}{|c|c|}
\hline Economic Criteria & Local Priority \\
\hline Price & 0.3770 \\
\hline Transportation Cost & 0.1019 \\
\hline Payment Term & 0.5212 \\
\hline Capability Criteria & Local Priority \\
\hline Supplier Capacity & 0.4263 \\
\hline Delivery Time & 0.0909 \\
\hline Percentage of Quality Reduction & 0.4828 \\
\hline Service Criteria & Local Priority \\
\hline Supplier Commitment & 0.3369 \\
\hline Supplier Policy & 0.6631 \\
\hline Price Sub Criteria & Local Priority \\
\hline Large Scale Supplier & 0.5858 \\
\hline Small Scale Supplier & 0.4142 \\
\hline Transportation Cost Sub Criteria & Local Priority \\
\hline Large Scale Supplier & 0.4568 \\
\hline Small Scale Supplier & 0.5432 \\
\hline Payment Term Sub Criteria & Local Priority \\
\hline Large Scale Supplier & 0.5858 \\
\hline Small Scale Supplier & 0.4142 \\
\hline Supplier Capacity Sub Criteria & Local Priority \\
\hline Large Scale Supplier & 0.7882 \\
\hline Small Scale Supplier & 0.2118 \\
\hline Delivery Time Sub Criteria & Local Priority \\
\hline Large Scale Supplier & 0.6505 \\
\hline Small Scale Supplier & 0.3495 \\
\hline Percentage of Quality Reduction Sub Criteria & Local Priority \\
\hline Large Scale Supplier & 0.4568 \\
\hline Small Scale Supplier & 0.5432 \\
\hline Supplier Commitment Sub Criteria & Local Priority \\
\hline Large Scale Supplier & 0.5180 \\
\hline Small Scale Supplier & 0.4820 \\
\hline Supplier Policy Sub Criteria & Local Priority \\
\hline Large Scale Supplier & 0.7883 \\
\hline Small Scale Supplier & 0.2118 \\
\hline Large Scale Supplier Sub Alternative & Local Priority \\
\hline B & 0.2596 \\
\hline $\mathrm{D}$ & 0.3874 \\
\hline E & 0.0627 \\
\hline $\mathrm{F}$ & 0.0655 \\
\hline $\mathrm{H}$ & 0.2249 \\
\hline Small Scale Supplier Sub Alternative & Local Priority \\
\hline I & 0.2612 \\
\hline $\mathrm{J}$ & 0.2137 \\
\hline $\mathrm{K}$ & 0.2073 \\
\hline $\mathrm{L}$ & 0.1467 \\
\hline M & 0.1711 \\
\hline
\end{tabular}




\section{Tabel 11}

Consistency checking result

\begin{tabular}{lllllll}
\hline & $\lambda \max$ & $\mathrm{n}$ & $\mathrm{CI}$ & $\mathrm{RI}$ & $\mathrm{CR}$ & Conclusion \\
\hline $\begin{array}{l}\text { Criteria Respect to Goal } \\
\begin{array}{l}\text { Sub Criteria respect to Economy } \\
\text { Criteria }\end{array}\end{array}$ & 3.0997 & 3 & 0.0498 & 0.52 & 0.0958 & Consistent \\
$\begin{array}{l}\text { Sub Criteria respect to Capability } \\
\text { Criteria }\end{array}$ & 3.1023 & 3 & 0.0512 & 0.52 & 0.0984 & Consistent \\
$\begin{array}{l}\text { Sub Alternatives respect to Large } \\
\text { Scale Supplier Alternative }\end{array}$ & 5.0993 & 3 & 0.0497 & 0.52 & 0.0955 & Consistent \\
$\begin{array}{l}\text { Sub alternatives respect to Small } \\
\text { Scale Supplier Alternatives }\end{array}$ & 5.2043 & 5 & 0.1083 & 1.11 & 0.0975 & Consistent \\
\hline
\end{tabular}

d. Calculating Overall Priority of the sub-alternative

The overall priority for each sub-alternative is obtained by summing the product of the local priority of the criterion priority times the local priority of the sub criteria times the local priority of alternatives time the local priority of sub alternatives with respect to that alternative, sub criterion and criterion. The results are presented in Table 12.

Table 12

Overall priority of each sub alternative

\begin{tabular}{llllll}
\hline Supplier & $\begin{array}{l}\text { Overall } \\
\text { priority }\end{array}$ & Rank & Supplier & $\begin{array}{l}\text { Overall } \\
\text { priority }\end{array}$ & Rank \\
\hline D (Large) & 0.2364 & 1 & K (Small) & 0.0808 & 6 \\
B (Large) & 0.1584 & 2 & M (Small) & 0.0667 & 7 \\
H (Large) & 0.1372 & 3 & L (Small) & 0.0572 & 8 \\
I (Small) & 0.1018 & 4 & F (Large) & 0.0399 & 9 \\
J (Small) & 0.0833 & 5 & E (Large) & 0.0383 & 10 \\
\hline
\end{tabular}

\section{Fuzzy AHP Methodology}

After performing AHP technique and the results were obtained, in order to observe how the experts will affect the result between AHP and FAHP, the FAHP was performed. We use three approached conducting FAHP in the research in this paper. First approach is using extent analysis proposed by Chang (1998); Second approach is using extent analysis proposed by Wang (2008) and third approach is by using modified fuzzy LLSM proposed by Wang (2008).

\subsection{FAHP using Extent Analysis}

Detail is explained:

a. Pairwise Comparison Matrix using Triangular Fuzzy Numbers (TFN)

Triangular Fuzzy Numbers (TFN) is a fuzzy set theory that helps expert in doing pairwise comparisons. TFN shows the subjectivity decision makers in linguistic variables and shows a definite degree of uncertainty (fuzzy). A tilde " $\sim$ " will be placed above a symbol if the symbol represents a fuzzy set (Kahraman et al, 2003). A triangular fuzzy number (TFN) is denoted as $\widetilde{M}$ and it consists of a value triplet $(l, m, u)$ where $l$ is a lower value, $m$ is middle value, and $u$ is upper grades and its membership value of TFN can be expressed as follows: (Meixner, 2009; Kahraman et al., 2003). 


$$
\mu(x \mid \tilde{M})=\left\{\begin{array}{c}
0, x<l \\
\frac{x-l}{m-l}, l \leq x \leq m \\
\frac{u-x}{u-m}, m \leq x \leq u \\
0, x>0
\end{array}\right.
$$

In the FAHP procedure, the pairwise comparisons in the judgment are fuzzy. The value of TFN in the fuzzy AHP are formed on the basis of a AHP pairwise comparison scale as follows and the detailed can be seen in Table 13.

$$
\tilde{1} \equiv(1,1,1), \tilde{x} \equiv(x-1, x, x+1) \forall x=2,3, \ldots, 8, \tilde{9} \equiv(9,9,9)
$$

\section{Tabel 13}

The value of TFN in the fuzzy AHP (Huang et al., 2014)

\begin{tabular}{llll}
\hline Judgment of preferences & Description & $\begin{array}{l}\text { Triangular Fuzzy Number } \\
(\text { TFN) }\end{array}$ & $\begin{array}{l}\text { Reciprocal of Triangular Fuzzy } \\
\text { Number }\end{array}$ \\
\hline 1 & Equally preferred & $(1,1,1)$ & $(1,1,1)$ \\
2 & Equally to moderately preferred & $(1,2,3)$ & $(1 / 3,1 / 2,1)$ \\
3 & Moderately preferred & $(2,3,4)$ & $(1 / 4,1 / 3,1 / 2)$ \\
4 & Moderately to strongly preferred & $(3,4,5)$ & $(1 / 6,1 / 5,1 / 3)$ \\
5 & Strongly preferred & $(4,5,6)$ & $(1 / 7,1 / 6,1 / 5)$ \\
6 & Strongly to very strongly preferred & $(5,6,7)$ & $(1 / 8,1 / 7,1 / 6)$ \\
7 & Very strongly preferred & $(6,7,8)$ & $(1 / 9,1 / 8,1 / 7)$ \\
9 & Strongly to extremely preferred & $(7,8,9)$ & $(1 / 9,1 / 9,1 / 9)$ \\
\hline
\end{tabular}

The pairwise comparison matrix FAHP can be expressed as:

$$
\tilde{M}=\left[\begin{array}{ccccc}
(1,1,1) & \cdot & \cdot & \cdot & \tilde{a}_{1 n} \\
\cdot & \cdot & & \cdot \\
\cdot & & \cdot & & \cdot \\
\cdot & & & \cdot & \cdot \\
\tilde{a}_{n 1} & & & & (1,1,1)
\end{array}\right]
$$

where $\tilde{a}_{i j}=\left(l_{i j}, m_{i j}, u_{i j}\right)=\tilde{a}_{j i}^{-1}=\left(1 / u_{j i}, 1 / m_{j i}, 1 / l_{j i}\right) ; i, j=1,2, \ldots, n$, and $i \neq j$

Pairwise comparison matrix FAHP among 4 experts in a glove manufacturer studied in this paper is shown Table 14.

\begin{tabular}{|c|c|c|c|c|c|c|c|c|c|}
\hline \multicolumn{10}{|c|}{ Expert 1 } \\
\hline Criteria & \multicolumn{3}{|c|}{ Economy } & \multicolumn{3}{|c|}{ Capability } & \multicolumn{3}{|c|}{ Service } \\
\hline Economy & 1.00 & 1.00 & 1.00 & 1.00 & 1.00 & 1.00 & 3.00 & 4.00 & 5.00 \\
\hline Capability & 1.00 & 1.00 & 1.00 & 1.00 & 1.00 & 1.00 & 4.00 & 5.00 & 6.00 \\
\hline Service & 0.20 & 0.25 & 0.33 & 0.17 & 0.20 & 0.25 & 1.00 & 1.00 & 1.00 \\
\hline \multicolumn{10}{|c|}{ Expert 2} \\
\hline Criteria & \multicolumn{3}{|c|}{ Economy } & \multicolumn{3}{|c|}{ Capability } & \multicolumn{3}{|c|}{ Service } \\
\hline Economy & 1.00 & 1.00 & 1.00 & 1.00 & 1.00 & 1.00 & 4.00 & 5.00 & 6.00 \\
\hline Capability & 1.00 & 1.00 & 1.00 & 1.00 & 1.00 & 1.00 & 4.00 & 5.00 & 6.00 \\
\hline Service & 0.17 & 0.20 & 0.25 & 0.17 & 0.20 & 0.25 & 1.00 & 1.00 & 1.00 \\
\hline \multicolumn{10}{|c|}{ Expert 3} \\
\hline Criteria & \multicolumn{3}{|c|}{ Economy } & \multicolumn{3}{|c|}{ Capability } & \multicolumn{3}{|c|}{ Service } \\
\hline Economy & 1.00 & 1.00 & 1.00 & 0.25 & 0.33 & 0.50 & 3.00 & 4.00 & 5.00 \\
\hline Capability & 2.00 & 3.00 & 4.00 & 1.00 & 1.00 & 1.00 & 5.00 & 6.00 & 7.00 \\
\hline Service & 0.20 & 0.25 & 0.33 & 0.14 & 0.17 & 0.20 & 1.00 & 1.00 & 1.00 \\
\hline \multicolumn{10}{|c|}{ Expert 4} \\
\hline Criteria & \multicolumn{3}{|c|}{ Economy } & \multicolumn{3}{|c|}{ Capability } & \multicolumn{3}{|c|}{ Service } \\
\hline Economy & 1.00 & 1.00 & 1.00 & 0.20 & 0.25 & 0.33 & 1.00 & 2.00 & 3.00 \\
\hline Capability & 3.00 & 4.00 & 5.00 & 1.00 & 1.00 & 1.00 & 5.00 & 6.00 & 7.00 \\
\hline Service & 0.33 & 0.50 & 1.00 & 0.14 & 0.17 & 0.20 & 1.00 & 1.00 & 1.00 \\
\hline
\end{tabular}

\section{Table 14}

Pair wise comparison matrix FAHP 
The next step is applying geometric mean to get the single value to be inputted in the pairwise comparison matrix using geometric mean of $l_{i j}, m_{i j}, u_{i j}$. According to Meixner (2009), the geometric mean can be computed as:

$$
\bar{l}_{i j}=\left(\prod_{k=1}^{k} l_{i j k}\right)^{\frac{1}{k}}, \bar{m}_{i j}=\left(\prod_{k=1}^{k} m_{i j k}\right)^{\frac{1}{k}}, \bar{u}_{i j}=\left(\prod_{k=1}^{k} u_{i j k}\right)^{\frac{1}{k}}
$$

Table 15

Geometric mean FAHP

\begin{tabular}{cccccccccc}
\hline Criteria & \multicolumn{3}{c}{ Economy } & \multicolumn{3}{c}{ Capability } & \multicolumn{3}{c}{ Service } \\
\hline Economy & 1.0000 & 1.0000 & 1.0000 & 0.4729 & 0.5373 & 0.6389 & 2.4495 & 3.5566 & 4.6058 \\
Capability & 1.5651 & 1.8612 & 2.1147 & 1.0000 & 1.0000 & 1.0000 & 4.4721 & 5.4772 & 6.4807 \\
Service & 0.2171 & 0.2812 & 0.4082 & 0.1543 & 0.1826 & 0.2236 & 1.0000 & 1.0000 & 1.0000 \\
\hline
\end{tabular}

b. Determine local priority using fuzzy synthetic extent $\left(\tilde{S}_{i}\right)$

In order to compute fuzzy synthetic extent $\left(\tilde{S}_{i}\right)$ to obtain local priority can be done using either the equation proposed by Chang (1998) or Wang (2008), which are presented in Equation 9 or 10, respectively. In this research of this paper, both two equations will be used and the result will be compared. The results are presented in Table 16.

$$
\tilde{S}_{i}=\sum_{j=1}^{m} \tilde{M}_{i}^{j} \odot\left[\sum_{i=1}^{n} \sum_{j=1}^{m} \tilde{M}_{i}^{j}\right]^{-1}
$$

where

$$
\begin{aligned}
& \sum_{j=1}^{m} \tilde{M}_{i}^{j}=\sum_{j=1}^{m} l_{j}, \sum_{j=1}^{m} m_{j}, \sum_{j=1}^{m} u_{j}\left[\sum_{i=1}^{n} \sum_{j=1}^{m} \tilde{M}_{i}^{j}\right]^{-1}=\frac{1}{\sum_{j=1}^{m} u_{j}, \sum_{j=1}^{m} m_{j}, \sum_{j=1}^{m} l_{j}} \\
& \tilde{S}_{i}=\frac{R S_{i}}{\sum_{j=1}^{n} R S_{j}}=\left(\frac{\sum_{j=1}^{n} l_{i j}}{\sum_{j=1}^{n} l_{i j}+\sum_{k=1, k \neq 1}^{n} \sum_{j=1}^{n} u_{k j}}, \frac{\sum_{j=1}^{n} m_{i j}}{\sum_{k=1}^{n} \sum_{j=1}^{n} m_{k j}}, \frac{\sum_{j=1}^{n} l_{i j}}{\sum_{j=1}^{n} u_{i j}+\sum_{k=1, k \neq 1}^{n} \sum_{j=1}^{n} l_{k j}}\right), i=1, \ldots, n
\end{aligned}
$$

\section{Table 16}

Local priority using fuzzy synthetic extent $\left(\tilde{S}_{i}\right)$ using Chang (1996) and Wang (2008) method

\begin{tabular}{lrrrrrr}
\hline Method & \multicolumn{3}{c}{ Chang (1996) } & \multicolumn{3}{c}{ Wang (2008) } \\
\hline$\left(\tilde{S}_{i}\right)$ & Economy & Capability & Service & Economy & Capability & Service \\
\hline Economy & 0.224498 & 0.341962 & 0.506423 & 0.258911 & 0.341962 & 0.426163 \\
Capability & 0.402772 & 0.559771 & 0.778153 & 0.471861 & 0.559771 & 0.644454 \\
Service & 0.078492 & 0.098267 & 0.132333 & 0.079679 & 0.098267 & 0.129596 \\
\hline
\end{tabular}

c. Compute the degree of possibility of $\tilde{S}_{i} \geq \tilde{S}_{j}$ by the following equation:

$$
V\left(\tilde{S}_{i} \geq \tilde{S}_{j}\right)= \begin{cases}1, & \text { if } m_{i} \geq m_{j} \\ \frac{u_{i}-l_{j}}{\left(u_{i}-m_{i}\right)+\left(m_{j}-l_{j}\right)}, & \text { if } l_{j} \leq u_{i} \quad i, j=1, \ldots, n ; j \neq i \\ 0, & \text { others }\end{cases}
$$


where $\tilde{S}_{i}=\left(l_{i}, m_{i}, u_{i}\right)$ and $\tilde{S}_{i}=\left(l_{j}, m_{j}, u_{j}\right)$

Calculation result of the degree of possibility is presented in Table 17.

Table 17

Degree of possibility

\begin{tabular}{lrrrrrr}
\hline Method & \multicolumn{3}{c}{ Chang (1996) } & \multicolumn{3}{c}{ Wang (2008) } \\
\hline$V\left(\tilde{S}_{i} \geq \tilde{S}_{j}\right)$ & Economy & Capability & Service & Economy & Capability & Service \\
\hline Economy & - & 0.3224 & 1.0000 & - & 0.0000 & 1.0000 \\
Capability & 1.0000 & - & 1.0000 & 1.0000 & - & 1.0000 \\
Service & 0.0000 & 0.0000 & - & 0.0000 & 0.0000 & - \\
\hline
\end{tabular}

d. Calculate the degree of possibility of $\tilde{S}_{i}$ over all the other $(n-1)$ fuzzy number by

$$
V\left(\tilde{S}_{i} \geq \tilde{S}_{j} \mid j=1, \ldots, n ; j \neq 1\right)=\min _{j \in\{1, \ldots, n\}, j \neq 1} V\left(\tilde{S}_{i} \geq \tilde{S}_{j}\right), i=1, \ldots, n
$$

The result is presented in Table 18 .

Table 18

Degree of possibility over all the other fuzzy number

\begin{tabular}{lll}
\hline Method & Chang (1996) & Wang (2008) \\
\hline Economy & 0.3224 & 0 \\
Capability & 1 & 1 \\
Service & 0 & 0 \\
\hline
\end{tabular}

e. Calculate the priority vector $W=\left(w_{1}, \ldots, w_{n}\right)^{T}$ of the fuzzy comparison matrix $\tilde{M}$

$$
w_{1}=\frac{V\left(\tilde{S}_{i} \geq \tilde{S}_{j} \mid j=1, \ldots, n ; j \neq i\right)}{\sum_{k=1}^{n} V\left(\tilde{S}_{k} \geq \tilde{S}_{j} \mid j=1, \ldots, n ; j \neq k\right)}, i=1, \ldots, n
$$

Hence, based on Eq. (13), the priority vector based on Chang and Wang method are $W=(0.2438,0.7562,0)^{T}$ and $W=(0,1,0)^{T}$, respectively. All steps above were performed and the result of the priority for each alternatives using Chang (1996)'s methods and Wang (2008)'s methods are presented in Table 19.

Table 19

Comparison of Local Priority Obtained by Chang (1996) and Wang (2008) method

\begin{tabular}{cccccc}
\hline Chang (1996) method & \multicolumn{5}{c}{ Wang (2008) method } \\
\hline Supplier & Local Priority & Rank & Supplier & Local Priority & Rank \\
\hline D (Large) & 0.2752 & 1 & I(Small) & 0.5430 & 1 \\
B(Large) & 0.2121 & 2 & K(Small) & 0.1444 & 2 \\
H(Large) & 0.1823 & 3 & J(Small) & 0.1421 & 3 \\
I(Small) & 0.1131 & 4 & D(Large) & 0.1027 & 4 \\
K(Small) & 0.0800 & 5 & B(Large) & 0.0392 & 5 \\
J(Small) & 0.0734 & 6 & H(Large) & 0.0286 & 7 \\
M (Small) & 0.0472 & 7 & E(Large) & 0 & 8 \\
L(Small) & 0.0167 & 8 & F(Large) & 0 & 9 \\
E(Large) & 0.0000 & 9 & L(Small) & 0 & 10 \\
F(Large) & 0.0000 & 10 & M(Small) & 0 & \\
\hline
\end{tabular}




\subsection{FAHP using LLSM}

Fuzzy LLSM developed following nonlinear optimization model proposed by Wang (2006) to criticize the extent analysis proposed by Chang (1996) as follows:

$\operatorname{Min} J=\sum_{i=1}^{n} \sum_{j=1, j \neq i}^{n}\left(\ln w_{i}^{L}-\ln w_{j}^{U}-\ln l_{i j}\right)^{2}+\left(\ln w_{i}^{M}-\ln w_{j}^{M}-\ln m_{i j}\right)^{2}+\left(\ln w_{i}^{M}-\ln w_{j}^{M}-\ln u_{i j}\right)^{2}$

subject to

$$
\begin{aligned}
& w_{i}^{L}+\sum_{j=1, j \neq i}^{n} w_{j}^{U} \geq 1, \quad i=1, \ldots, n \\
& w_{i}^{U}+\sum_{j=1, j \neq i}^{n} w_{j}^{L} \leq 1, \quad i=1, \ldots, n \\
& \sum_{i=1}^{n}\left(w_{i}^{L}+w_{i}^{U}\right)=2, \quad i=1, \ldots, n \\
& w_{i}^{U} \geq w_{i}^{M} \geq w_{i}^{L}>0, \quad i=1, \ldots, n \\
& \sum_{i=1}^{n} w_{i}^{M}=1
\end{aligned}
$$

According to Wang (2008), the above model can produce normalized triangular fuzzy weight $\tilde{w}_{i}=\left(w_{i}^{L}, w_{i}^{M}, w_{i}^{U}\right), i=1, \ldots, n$. Global fuzzy weight of alternative $A_{k}(k=1, \ldots, K)$ can be obtained by solving two sets of linear programming and one equation below:

$$
w_{A_{k}}^{L}=\min \sum_{j=1}^{m} w_{k j}^{L} w_{j}
$$

subject to

$$
\begin{gathered}
w_{j}^{L} \leq w_{j} \leq w_{j}^{U}, \quad j=1, \ldots, m \\
\sum_{j=1}^{m} w_{j}=1 \\
w_{A_{k}}^{U}=\max \sum_{j=1}^{m} w_{k j}^{U} w_{j}
\end{gathered}
$$

subject to

$$
\begin{gathered}
w_{j}^{L} \leq w_{j} \leq w_{j}^{U}, \quad j=1, \ldots, m \\
\sum_{j=1}^{m} w_{j}=1 \\
w_{A_{k}}^{M}=\sum_{j=1}^{m} w_{k j}^{M} w_{j}^{M}
\end{gathered}
$$

To solve the problem presented in this paper, the fuzzy LLSM model proposed by Wang (2006) was solved using optimization software which is Lingo 7 and the results are presented in Table 20 and 21.

\section{Table 20}

Priority Vectors Resulted by the Fuzzy LLSM Model

\begin{tabular}{lccc}
\hline Criteria & $w_{j}^{L}$ & $w_{j}^{M}$ & $w_{j}^{U}$ \\
\hline Economy & 0.289506 & 0.328213 & 0.366565 \\
Capability & 0.548532 & 0.573484 & 0.589703 \\
Service & 0.084903 & 0.098304 & 0.120791 \\
\hline Sub Criteria Economy & & & \\
Price & 0.368124 & 0.388624 & 0.406764 \\
Transportation cost & 0.083972 & 0.100446 & 0.125762 \\
Payment Term & 0.500609 & 0.510929 & 0.514770 \\
\hline
\end{tabular}


Table 20

Priority Vectors Resulted by the Fuzzy LLSM Model (Continued)

\begin{tabular}{|c|c|c|c|}
\hline Criteria & $w_{j}^{L}$ & $w_{j}^{M}$ & $w_{j}^{U}$ \\
\hline \multicolumn{4}{|c|}{ Sub Criteria Capability } \\
\hline Supplier Capacity & 0.348642 & 0.432410 & 0.462625 \\
\hline Delivery Time & 0.083854 & 0.095083 & 0.101231 \\
\hline Quality Reduction & 0.453522 & 0.472506 & 0.550127 \\
\hline \multicolumn{4}{|l|}{ Sub Criteria Service } \\
\hline Supplier Commitment & 0.311200 & 0.336928 & 0.372885 \\
\hline Supplier Policy & 0.627115 & 0.663072 & 0.688800 \\
\hline \multicolumn{4}{|l|}{ Price Sub Criteria } \\
\hline Large Scale Supplier & 0.431765 & 0.456786 & 0.500000 \\
\hline Small Scale Supplier & 0.500000 & 0.543214 & 0.568235 \\
\hline \multicolumn{4}{|c|}{ Transportation Cost Sub Criteria } \\
\hline Large Scale Supplier & 0.568235 & 0.585786 & 0.599254 \\
\hline Small Scale Supplier & 0.400746 & 0.414214 & 0.431765 \\
\hline \multicolumn{4}{|c|}{ Payment Term Sub Criteria } \\
\hline Large Scale Supplier & 0.568235 & 0.585786 & 0.599254 \\
\hline Small Scale Supplier & 0.400746 & 0.414214 & 0.431765 \\
\hline \multicolumn{4}{|c|}{ Supplier Capacity Sub Criteria } \\
\hline Large Scale Supplier & 0.730517 & 0.788244 & 0.825441 \\
\hline Small Scale Supplier & 0.174559 & 0.211756 & 0.269483 \\
\hline \multicolumn{4}{|c|}{ Delivery Time Sub Criteria } \\
\hline Large Scale Supplier & 0.610149 & 0.650498 & 0.678946 \\
\hline Small Scale Supplier & 0.321054 & 0.349502 & 0.389851 \\
\hline \multicolumn{4}{|c|}{ Percentage of Quality Reduction Sub Criteria } \\
\hline Large Scale Supplier & 0.431765 & 0.456786 & 0.500000 \\
\hline Small Scale Supplier & 0.500000 & 0.543214 & 0.568235 \\
\hline \multicolumn{4}{|c|}{ Supplier Commitment Sub Criteria } \\
\hline Large Scale Supplier & 0.482028 & 0.517972 & 0.557019 \\
\hline Small Scale Supplier & 0.442981 & 0.482028 & 0.517972 \\
\hline \multicolumn{4}{|c|}{ Supplier Policy Sub Criteria } \\
\hline Large Scale Supplier & 0.730517 & 0.788244 & 0.825441 \\
\hline Small Scale Supplier & 0.174559 & 0.211756 & 0.269483 \\
\hline \multicolumn{4}{|c|}{ Large Scale Supplier Sub Alternative } \\
\hline $\mathrm{B}$ & 0.256923 & 0.279581 & 0.314403 \\
\hline $\mathrm{D}$ & 0.325833 & 0.361506 & 0.387512 \\
\hline $\mathrm{E}$ & 0.054482 & 0.058482 & 0.065412 \\
\hline $\mathrm{F}$ & 0.062402 & 0.068834 & 0.078839 \\
\hline $\mathrm{H}$ & 0.211522 & 0.231597 & 0.242672 \\
\hline \multicolumn{4}{|c|}{ Small Scale Supplier Sub Alternative } \\
\hline I & 0.250010 & 0.262719 & 0.278964 \\
\hline J & 0.179447 & 0.207343 & 0.229702 \\
\hline $\mathrm{K}$ & 0.188431 & 0.210347 & 0.237566 \\
\hline $\mathrm{L}$ & 0.132616 & 0.148737 & 0.167196 \\
\hline M & 0.160110 & 0.170854 & 0.175959 \\
\hline
\end{tabular}

Table 21

Global Fuzzy Weights

\begin{tabular}{cccc}
\hline Supplier $A_{k}$ & $w_{A_{k}}^{L}$ & $w_{A_{k}}^{M}$ & $w_{A_{k}}^{U}$ \\
\hline D & 0.176385 & 0.216564 & 0.251166 \\
B & 0.139081 & 0.167486 & 0.203781 \\
H & 0.114504 & 0.138741 & 0.157288 \\
I & 0.087966 & 0.105334 & 0.127951 \\
K & 0.066299 & 0.084336 & 0.108963 \\
J & 0.063138 & 0.083132 & 0.105356 \\
M & 0.056335 & 0.068502 & 0.080706 \\
L & 0.046661 & 0.059635 & 0.076687 \\
F & 0.033780 & 0.041236 & 0.051100 \\
E & 0.029493 & 0.035034 & 0.042397 \\
\hline
\end{tabular}




\section{Discussion}

Table 22 merged all the priority rank obtained from AHP method and Fuzzy AHP methods. It is clearly shown that the result of AHP method, Fuzzy AHP using Chang's (1996) Extent Analysis, and Fuzzy AHP LLSM are quite similar, in which priority rank 1-4 (Supplier D, B, H, I) and 7-8 (Supplier M, L) are exactly the same. For the purpose of decision making in the company, therefore, the company can utilize this priority list, i.e. supplier D is the first priority, supplier B is the second priority, etc.

Once again the result of this research is raising the question whether fuzzy AHP is necessary to apply, especially when the decision is involving qualified expert, i.e. this research were using experts who has more than 12 years experiences. This research emphasizes some comparative analysis between fuzzy AHP and AHP, i.e. Kabir and Hasin (2011), Özdağoğlu and Özdağoğlu (2007), that the top priorities from both methods are actually the same. In particular, the first four priorities are the same.

Table 22

Comparison of Priority Rank Among Methods

\begin{tabular}{lcccc}
\hline Priority Rank & AHP & $\begin{array}{c}\text { Fuzzy AHP Extent } \\
\text { Analysis Chang } \\
(1996)\end{array}$ & $\begin{array}{c}\text { Fuzzy AHP Extent } \\
\text { Analysis Wang } \\
(2008)\end{array}$ & Fuzzy AHP LLSM \\
\hline 1 & D & D & I & D \\
2 & B & B & K & B \\
3 & H & H & J & H \\
4 & I & I & D & K \\
5 & $\mathrm{~J}$ & K & B & J \\
6 & K & J & H & M \\
7 & M & M & E & F \\
8 & L & L & F & E \\
\hline 9 & F & E & L & M \\
\hline
\end{tabular}

It is also shown from the Table 22 above that the result of Fuzzy AHP using Wang's (2008) Extent Analysis is totally different with the result of three other methods. Although this method is claimed as the mathematical correction of the Chang's (1996) Extent Analysis, however, it is caused a lot of zero value of possibility. This zero value of possibility caused some of the local priority is also zero and finally affecting the final priority rank.

For this particular case study, therefore, one does not need to apply Fuzzy AHP for developing the priority list of supplier due to theses three following reasons: a) the top priorities resulted from AHP and Fuzzy AHP are the same, b) the mathematical arguable on which fuzzy methods should be applied, c) the Fuzzy AHP requires more complicated process and takes longer time than AHP.

\section{Conclusion}

The supplier selection problem for this company can be formulated as hierarchy presented in Figure 2, which is consist of 4 level with three criteria, eight sub criteria, two alternatives, and ten sub alternatives. Finally, the company can use the priority rank of supplier as the basis of their procurement process, which is summarized in Table 22, i.e. supplier D, B, H, I, K or L, M, L, and F or E.

In the AHP methodology, this research emphasizes the unnecessary use of the Fuzzy AHP, especially whenever the decision making process is supported by 'expert' respondents. In such case, the AHP is sufficient for making the decision. 


\section{References}

Agarwal, P., Sahai, M., Mishra, V., Bag, M., \& Singh, V. (2011). A review of multi-criteria decision making techniques for supplier evaluation and selection. International Journal of Industrial Engineering Computations, 2(4), 801-810.

Asamoah, D., Annan, J., \& Nyarko, S. (2012). AHP approach for supplier evaluation and selection in a pharmaceutical manufacturing firm in Ghana. International Journal of Business and Management, 7(10), 49-62

Azizi, M., \& Modarres, M. (2010). A decision model to select facial tissue raw material: A case from Iran. OR Insight, 23(4), 207-232.

Benyoucef, M., \& Canbolat, M. (2007). Fuzzy AHP-based supplier selection in eprocurement. International Journal of Services and Operations Management, 3(2), 172-192.

Bhutta, K. S., \& Huq, F. (2002). Supplier selection problem: a comparison of the total cost of ownership and analytic hierarchy process approaches. Supply Chain Management: An International Journal, 7(3), 126-135.

Bruno, G., Esposito, E., Genovese, A., \& Passaro, R. (2012). AHP-based approaches for supplier evaluation: Problems and perspectives. Journal of Purchasing and Supply Management, 18(3), 159172.

Çebi, F., \& Bayraktar, D. (2003). An integrated approach for supplier selection. Logistics Information Management, 16(6), 395-400.

Chamodrakas, I., Batis, D., \& Martakos, D. (2010). Supplier selection in electronic marketplaces using satisficing and fuzzy AHP. Expert Systems with Applications, 37(1), 490-498.

Chan, F. T. S., \& Kumar, N. (2007). Global supplier development considering risk factors using fuzzy extended AHP-based approach. Omega, 35(4), 417-431.

Chan, F. T., \& Chan, H. K. (2004). Development of the supplier selection model - a case study in the advanced technology industry. Proceedings of the Institution of Mechanical Engineers, Part B: Journal of Engineering Manufacture, 218(12), 1807-1824.

Chan, F. T., \& Chan, H. K. (2010). An AHP model for selection of suppliers in the fast changing fashion market. The International Journal of Advanced Manufacturing Technology, 51(9-12), 1195-1207.

Chan, F. T., Kumar, N., Tiwari, M. K., Lau, H. C. W., \& Choy, K. L. (2008). Global supplier selection: a fuzzy-AHP approach. International Journal of Production Research, 46(14), 3825-3857.

Chan, F.T.S. (2003). Interactive selection model for supplier selection process: an analytical hierarchy process approach. International Journal of Production Research, 41(15), 3549-3579.

Chang, D. Y. (1996). Applications of the extent analysis method on fuzzy AHP. European Journal of Operational Research, 95(3), 649-655.

Che, Z. H. (2010). A genetic algorithm-based model for solving multi-period supplier selection problem with assembly sequence. International Journal of Production Research, 48(15), 43554377.

Chen, C. T., Lin, C. T., \& Huang, S. F. (2006). A fuzzy approach for supplier evaluation and selection in supply chain management. International Journal of Production Economics, 102(2), 289-301.

Choi, J. H., \& Chang, Y. S. (2006). A two-phased semantic optimization modeling approach on supplier selection in eProcurement. Expert Systems with Applications, 31(1), 137-144.

Choi, T. Y., \& Hartley, J. L. (1996). An exploration of supplier selection practices across the supply chain. Journal of Operations Management, 14(4), 333-343.

Choy, K. L., Lee, W., \& Lo, V. (2003). Design of a case based intelligent supplier relationship management system - the integration of supplier rating system and product coding system. Expert Systems with Applications,25(1), 87-100.

De Boer, L., Labro, E., \& Morlacchi, P. (2001). A review of methods supporting supplier selection. European Journal of Purchasing \& Supply Management, 7(2), 75-89.

Degraeve, Z., Labro, E., \& Roodhooft, F. (2000). An evaluation of vendor selection models from a total cost of ownership perspective. European Journal of Operational Research, 125(1), 34-58. 
Fawcett, S. E., Stanley, L. L., \& Smith, S. R. (1997). Developing a logistics capability to improve the performance of international operations. Journal of Business Logistics, 18(2), 101-127

Gencer, C., \& Gürpinar, D. (2007). Analytic network process in supplier selection: A case study in an electronic firm. Applied Mathematical Modelling, 31(11), 2475-2486.

Ghodsypour, S. H., \& O'Brien, C. (1998). A decision support system for supplier selection using an integrated analytic hierarchy process and linear programming. International Journal of Production Economics, 56, 199-212.

Gnanasekaran, S., Velappan, S., \& Manimaran, P. (2006). Application of analytical hierarchy process in supplier selection: an automobile industry case study. South Asian Journal of Management, 13(4), 89.

Gonzalez, M. E., Quesada, G., \& Mora Monge, C. A. (2004). Determining the importance of the supplier selection process in manufacturing: a case study. International Journal of Physical Distribution \& Logistics Management, 34(6), 492-504.

Haq, A. N., \& Kannan, G. (2006). Fuzzy analytical hierarchy process for evaluating and selecting a vendor in a supply chain model. The International Journal of Advanced Manufacturing Technology, 29(7-8), 826-835.

Holt, G. D. (1998). Which contractor selection methodology?. International Journal of Project Management, 16(3), 153-164.

Hou, J., \& Su, D. (2006). Integration of web services technology with business models within the total product design process for supplier selection. Computers in Industry, 57(8), 797-808.

Hsu, C. W., Kuo, R. J., \& Chiou, C. Y. (2014). A multi-criteria decision-making approach for evaluating carbon performance of suppliers in the electronics industry. International Journal of Environmental Science and Technology, 11(3), 775-784.

Huang, S. Y., Wang, C. Y., \& Chiou, C. Y. (2014). FAHP Application for Green Supplier Selection in Electronic Industry. The Journal of Human Resource and Adult Learning, 10(2), 49-60.

Jabbour, A. B. L., \& Jabbour, C. J. (2009). Are supplier selection criteria going green? Case studies of companies in Brazil. Industrial Management \& Data Systems, 109(4), 477-495.

Jayaraman, V., Srivastava, R., \& Benton, W. C. (1999). Supplier selection and order quantity allocation: a comprehensive model. Journal of Supply Chain Management, 35(1), 50-58.

Kabir, G., \& Hasin, M. A. A. (2011). Comparative analysis of AHP and Fuzzy AHP models for multicriteria inventory classification. International Journal of Fuzzy Logic Systems, 1(1), 1-16.

Kahraman, C., Cebeci, U., \& Ulukan, Z. (2003). Multi-criteria supplier selection using fuzzy AHP. Logistics Information Management, 16(6), 382-394.

Kang, H. Y., \& Lee, A. H. (2010). A new supplier performance evaluation model: A case study of integrated circuit (IC) packaging companies. Kybernetes, 39(1), 37-54.

Kannan, D., Khodaverdi, R., Olfat, L., Jafarian, A., \& Diabat, A. (2013). Integrated fuzzy multi criteria decision making method and multi-objective programming approach for supplier selection and order allocation in a green supply chain. Journal of Cleaner Production, 47, 355-367.

Khorasani, O., \& Bafruei, M. K. (2011). A fuzzy AHP approach for evaluating and selecting supplier in pharmaceutical industry. International Journal of Academic Research, 3(1). 346-352

Kilincci, O., \& Onal, S. A. (2011). Fuzzy AHP approach for supplier selection in a washing machine company. Expert Systems with Applications, 38(8), 9656-9664.

Kokangul, A., \& Susuz, Z. (2009). Integrated analytical hierarch process and mathematical programming to supplier selection problem with quantity discount. Applied Mathematical Modelling, 33(3), 1417-1429.

Kumar Kar, A., \& K. Pani, A. (2014). Exploring the importance of different supplier selection criteria. Management Research Review, 37(1), 89-105.

Kuo, R. J., Lee, L. Y., \& Hu, T. L. (2010). Developing a supplier selection system through integrating fuzzy AHP and fuzzy DEA: a case study on an auto lighting system company in Taiwan. Production Planning and Control,21(5), 468-484.

Li, C. C., Fun, Y. P., \& Hung, J. S. (1997). A new measure for supplier performance evaluation. IIE Transactions, 29(9), 753-758. 
Li, Z., Wong, W. K., \& Kwong, C. K. (2013). An integrated model of material supplier selection and order allocation using fuzzy extended AHP and multiobjective programming. Mathematical Problems in Engineering, 2013. Article ID 363718

Liu, F. H. F., \& Hai, H. L. (2005). The voting analytic hierarchy process method for selecting supplier. International Journal of Production Economics,97(3), 308-317.

Mafakheri, F., Breton, M., \& Ghoniem, A. (2011). Supplier selection-order allocation: A two-stage multiple criteria dynamic programming approach. International Journal of Production Economics, 132(1), 52-57.

Meixner, O. (2009). Fuzzy AHP group decision analysis and its application for the evaluation of energy sources. In Proceedings of the 10th International Symposium on the Analytic Hierarchy/Network Process, Pittsburgh, PA, USA (Vol. 29).

Mendoza, A. (2007). Effective Methodologies For Supplier Selection And Order Quantity Allocation. Ph.D. Thesis, Pennsylvania State University.

Mendoza, A., Santiago, E., \& Ravindran, A.R. (2008). A three-phase multicriteria method to the supplier selection problem. International Journal of Industrial Engineering, 15(2), 195-210.

Mirabi, M., Ghomi, F., \& Jolai, F. (2010). A Hybrid Electromagnetism-Like Algorithm for Supplier Selection in Make-to-Order Planning. Scientia Iranica Transaction E: Industrial Engineering, 17(1), 1-11.

Mohaghar, A., Fathi, M.R., Jafarzadeh, A.H. (2013). A supplier selection method using AR-DEA and fuzzy VIKOR. International Journal of Industrial Engineering, 20 (5-6), 387-400.

Motwani, J., Larson, L., \& Ahuja, S. (1998). Managing a global supply chain partnership. Logistics Information Management, 11(6), 349-354.

Nayak, J. K., Sinha, G., \& Guin, K. K. (2011). Impact of supplier management on a firm's performance. Decision, 38(1), 77-90.

Nazari-Shirkouhi, S., Shakouri, H., Javadi, B., \& Keramati, A. (2013). Supplier selection and order allocation problem using a two-phase fuzzy multi-objective linear programming. Applied Mathematical Modelling, 37(22), 9308-9323.

Olhager, J., \& Selldin, E. (2004). Supply chain management survey of Swedish manufacturing firms. International Journal of Production Economics, 89(3), 353-361.

Özdağoğlu, A., \& Özdağoğlu, G. (2007). Comparison of AHP and fuzzy AHP for the multi-criteria decision making processes with linguistic evaluations. Ístanbul Ticaret Üniversitesi Fen Bilimleri Dergisi, 6(11), 65-85

Paksoy, T., Özceylan, E., \& Weber, G. W. (2013). Profit oriented supply chain network optimization. Central European Journal of Operations Research, 21(2), 455-478.

Perçin, S. (2006). An application of the integrated AHP-PGP model in supplier selection. Measuring Business Excellence, 10(4), 34-49.

Qiang, R., \& Li, D. (2015). An Inhomogeneous Multi-Attribute Decision Making Method and Application to IT/IS Outsourcing Provider Selection. International Journal of Industrial Engineering, 22(2), 252-266.

Rajesh, G., \& Malliga, P. (2013). Supplier selection based on AHP QFD methodology. Procedia Engineering, 64, 1283-1292.

Ramanathan, R. (2007). Supplier selection problem: integrating DEA with the approaches of total cost of ownership and AHP. Supply Chain Management: an International Journal, 12(4), 258-261.

Rezaei, J., Fahim, P. B., \& Tavasszy, L. (2014). Supplier selection in the airline retail industry using a funnel methodology: Conjunctive screening method and fuzzy AHP. Expert Systems with Applications, 41(18), 8165-8179.

Ruiz-Torres, A. J., Mahmoodi, F., \& Zeng, A. Z. (2013). Supplier selection model with contingency planning for supplier failures. Computers \& Industrial Engineering, 66(2), 374-382.

Saaty, T. L. (1994). Fundamental of Decision Making \& Priority Theory with the Analytical Hierarchy Process, RWS Publication, Pittsburgh.

Saaty, T. L. (1980). The Analytic hierarchy process. McGraw-Hill, New York, NY. 
Sagar, M. K., \& Singh, D. (2012). Supplier selection criteria: Study of automobile sector in India. International Journal of Engineering Research and Development, 4(4), 34-39.

Sevkli, M., Lenny Koh, S. C., Zaim, S., Demirbag, M., \& Tatoglu, E. (2007). An application of data envelopment analytic hierarchy process for supplier selection: a case study of BEKO in Turkey. International Journal of Production Research, 45(9), 1973-2003.

Shaw, K., Shankar, R., Yadav, S. S., \& Thakur, L. S. (2012). Supplier selection using fuzzy AHP and fuzzy multi-objective linear programming for developing low carbon supply chain. Expert Systems with Applications, 39(9), 8182-8192.

Songhori, M. J., Tavana, M., Azadeh, A., \& Khakbaz, M. H. (2011). A supplier selection and order allocation model with multiple transportation alternatives. The International Journal of Advanced Manufacturing Technology, 52(1-4), 365-376.

Talluri, S. (2002). A buyer-seller game model for selection and negotiation of purchasing bids. European Journal of Operational Research, 143(1), 171-180.

Talluri, S., \& Narasimhan, R. (2003). Vendor evaluation with performance variability: A max-min approach. European Journal of Operational Research,146(3), 543-552.

Thakkar, J., Kanda, A., \& Deshmukh, S. G. (2012). Supply chain issues in Indian manufacturing SMEs: insights from six case studies. Journal of Manufacturing Technology Management, 23(5), 634-664.

Timmerman, E. (1987). An approach to vendor performance evaluation. IEEE Engineering Management Review, 3(15), 14-20.

Tyagi, M., Kumar, P., \& Kumar, D. (2015). Permutation of fuzzy AHP and AHP methods to prioritizing the alternatives of supply chain performance system. International Journal of Industrial Engineering, 22(6), 729-752.

Vonderembse, M. A., \& Tracey, M. (1999). The impact of supplier selection criteria and supplier involvement on manufacturing performance. Journal of Supply Chain Management, 35(2), 33-39.

Wang, Y. M., Elhag, T. M., \& Hua, Z. (2006). A modified fuzzy logarithmic least squares method for fuzzy analytic hierarchy process. Fuzzy Sets and Systems, 157(23), 3055-3071.

Wang, Y. M., Luo, Y., \& Hua, Z. (2008). On the extent analysis method for fuzzy AHP and its applications. European Journal of Operational Research,186(2), 735-747.

Weber, C. A., \& Ellram, L. M. (1993). Supplier selection using multi-objective programming: a decision support system approach. International Journal of Physical Distribution \& Logistics Management, 23(2), 3-14.

Weber, C. A., Current, J. R., \& Benton, W. C. (1991). Vendor selection criteria and methods. European Journal of Operational Research, 50(1), 2-18.

Wilson, E. J. (1994). The relative importance of supplier selection criteria: a review and update. International Journal of Purchasing and Materials Management, 30(2), 34-41.

Yadav, V., \& Sharma, M. K. (2015). An application of hybrid data envelopment analytical hierarchy process approach for supplier selection. Journal of Enterprise Information Management, 28(2), 218242.

Yadav, V., \& Sharma, M. K. (2016). Multi-criteria supplier selection model using the analytic hierarchy process approach. Journal of Modelling in Management, 11(1), 326-354.

Yildiz, A., \& Yayla, A. Y. (2015). Multi-criteria decision-making methods for supplier selection: A literature review. South African Journal of Industrial Engineering, 26(2), 158-177.

Yu, C., \& Wong, T. N. (2014). A supplier pre-selection model for multiple products with synergy effect. International Journal of Production Research, 52(17), 5206-5222.

Zhu, J. (2004). A buyer-seller game model for selection and negotiation of purchasing bids: extensions and new models. European Journal of Operational Research, 154(1), 150-156.

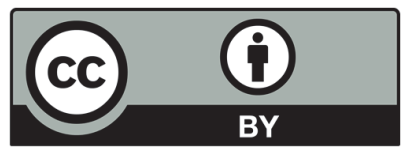

(C) 2020 by the authors; licensee Growing Science, Canada. This is an open access article distributed under the terms and conditions of the Creative Commons Attribution (CC-BY) license (http://creativecommons.org/licenses/by/4.0/). 